\title{
Preliminary Recognition of River Infrastructure
}

\author{
Mahendra Andiek Maulana ${ }^{1, a)}$, Hitapriya Suprayitno ${ }^{1, b)}$ \& Ria Asih Aryani Soemitro ${ }^{1, c)}$ \\ ${ }^{1)}$ Civil Engineering Departement, Institut Teknologi Sepuluh Nopember, Surabaya, Indonesia. \\ Corespondance : ${ }^{a}$ mahendrasipil@gmail.com, ${ }^{b}$ suprayitno.hita@gmail.com \& \\ ${ }^{c}$ soemitroraa@gmail.com
}

\begin{abstract}
River infrastructures can be defined as facilities and structures that support all activities related to river. Many infrastructures that exist along river stream but few of them are listed and recognized as an important part in the river system. The condition of assets that support the river function should be considered since it determines the sustainability of water supply system for many areas. Starting from upstream, there were dam and reservoir that constructed to reserve the water. Moreover, the water can be distributed to the downstream area for many requirements, such as irrigation system, hydro power, industrial process, etc. In the other hand, dam and reservoir also functioned as flood control that protect the downstream area from flood and inundation. In alluvial river, there were erosions that occurs as river flow velocity could transported soft soil numerously. Hence, the river bank protections were built in order to protect the nearby river infrastructures. Therefore, the infrastructures recognition as preliminary assessment to the river asset management need to be done in order to maintain the river system.
\end{abstract}

Keywords : infrastructure asset management, river infrastructure, asset, function, flood, reservoir.

\section{INTRODUCTION}

River has many advantages as it provides fresh water sources for numerous necessities (Angriani et al., 2018). In order to ensure the existence of water, some structural buildings such as dam, ground sill, river revetment, embankment, etc. were built. These structures are categorized as river infrastructure since the functions correlated to the river operations. The recognition of river infrastructure is corresponding to the asset management, hence the river system can be managed comprehensively (Budryte et al. 2018; Soemitro \& Suprayitno 2018; Suprayitno \& Soemitro 2018). Furthermore, the concept of river management is stated in Integrated Water Resources Management (IWRM) that provides a guideline in regulating a whole river system. It will need the coordination between stakeholders that involved in certain river basin (Campbell, 2016). It can be understood that to manage a whole river basin requires collaboration from multi discipline. This condition reflected in the implementation of infrastructure along river stream. Starting from upstream area, the construction of dam involving several stakeholders such as, civil engineering, mechanical engineering, electrical engineering, biologist, social expertise, etc. In some case, the analysis to recognize the water leakage is conducting to identify the potential water losses along the river stream (Bonthuys et al., 2019).

This paper presents several types of river infrastructures as an effort to identify that assets, hence the appropriate planning, operation and maintenance could be well arranged. 


\section{PRELIMINARY RECONGNITION OF RIVER INFRASTRUCTURE}

\section{River, Utilization and Risk}

River is one of natural phenomenon which formed by multivarious events such as geology, hydrology, climate, etc. It flows from the mountainous area into another water body such as lake, ocean, reservoir or the downstream river. Each river has its own area which defined by topographical circumstance, called catchment area. According to the geological condition, the morphology would be defined as an alluvial or non-alluvial river (Church, 2006). In alluvial river, the morphology tends to change frequently as it formed on the sediment deposit.

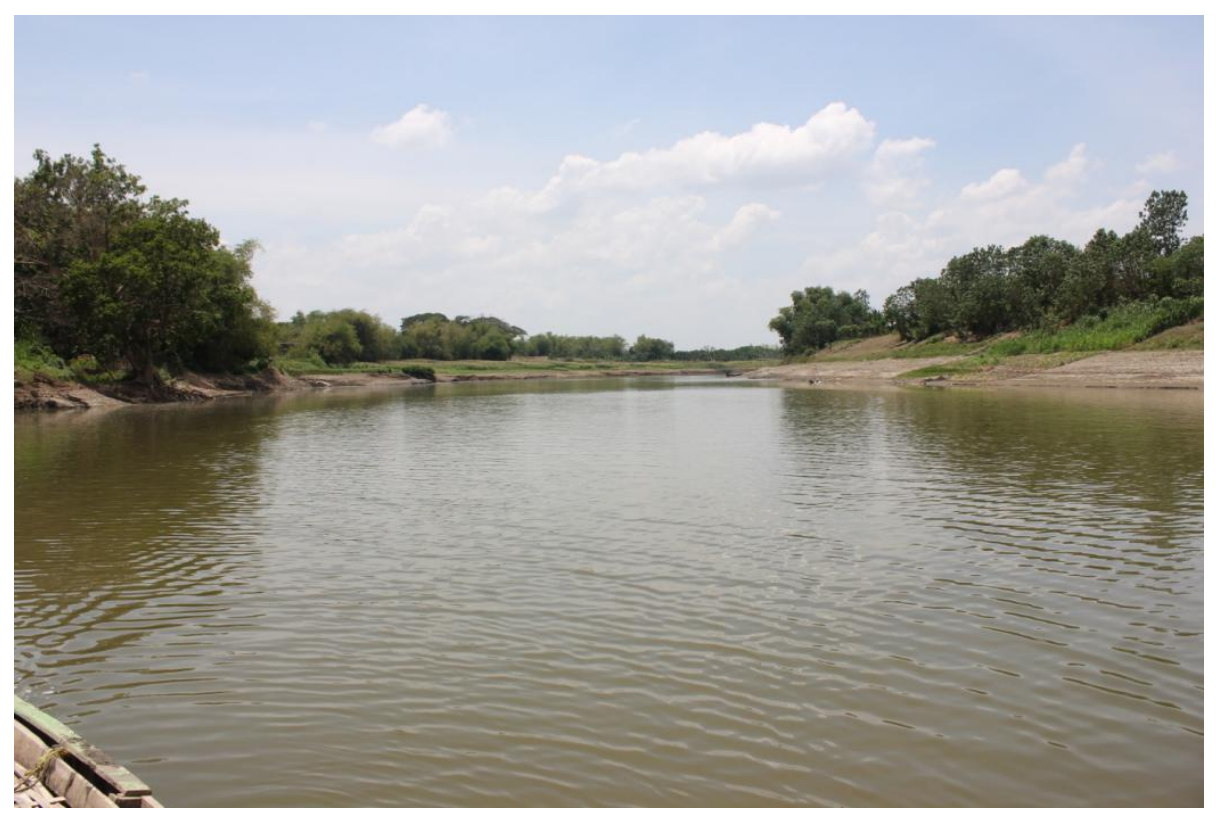

Figure 1. Bengawan Solo River at Bojonegoro, East Java Province

River has many functions in various aspects. It become primary drainage system in certain catchment area which functions as water storage. Therefore, the river is play an important role in flood and inundation occurrences. The river capacity should be maintained in accordance with flood frequency design. Sediment and erosion often cause changes of river capacity in many areas (Tarrio et al., 2019). Hence, the river as one of water resources asset should be maintained to ensure its function as flood control. In the other hand, the irrigation system, fresh water supply, hydro power etc. also depends on the river. With the amount of river water, all of requirements can be fulfilled by appropriate and integrated management.

\section{Dam}

Dam is designed to block river flow in certain area, thus the water will be accumulated in the reservoir as fresh water sources (Mettetal, 2019). According to its size, there are two types of dam, large and small dam. Large dam has more than $15 \mathrm{~m}$ of height, measured from the foundation to the top of dam. In the other hand, the criteria of small dam is given if the total height of dam less than $15 \mathrm{~m}$. moreover, reservoir capacity and flow discharge also determining the dam criteria. Meanwhile, based on material structure, the dam can be classified into earth fill dam and concrete dam. Most of dam constructions were earth fill type due to ease and flexibility in construction method (Luo et al., 2019). In certain area, concrete dam was chosen due to topographic and geological conditions. 


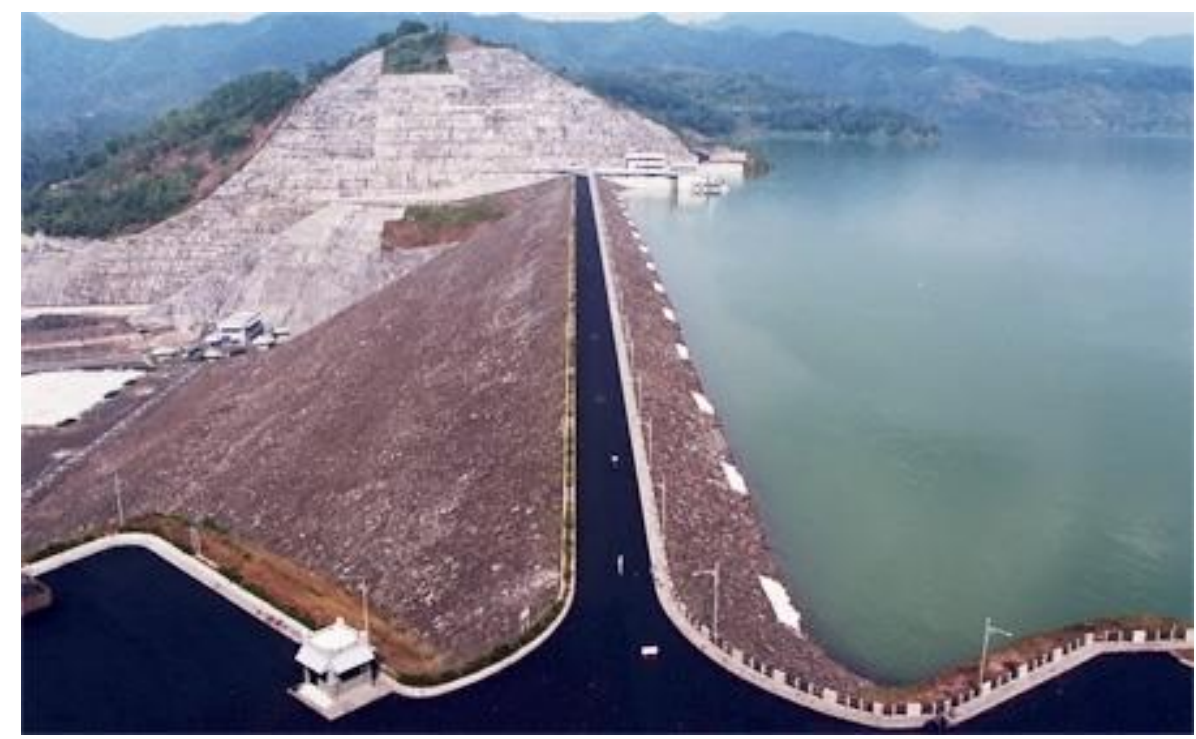

Figure 2. Earth fill dam type (Source: http://indotravelplace.blogspot.com, 2015)

\section{Weir}

Weir is one of the most important infrastructures in irrigation systems as it requires water supply which taken from river. Generally, the river water level is located below the cultivated land elevation. Hence, weir is widely used to elevate river water level as irrigation system requirements (Saleh et al., 2019). There are two type of weir, fixed and movable weir. Fixed weir is usually constructed by concrete structures with spillway and flushing gate, while the movable weir is constructed by several gate that can be controlled as operation standard design. The irrigation intake is usually located at the upstream of weir next to flushing gate. The water will be flown trough irrigation intake when the water level is higher than irrigation channel bed level. Therefore, the condition of weir and its facility should be maintained as it plays an important role in irrigation system.

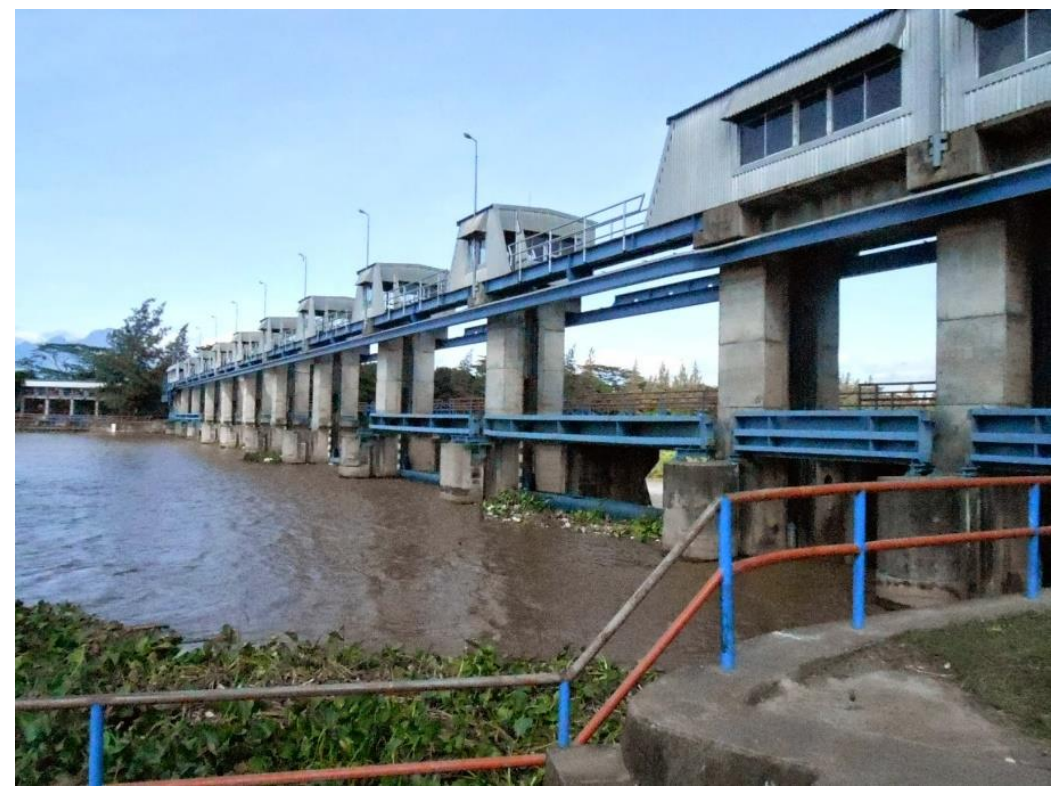

Figure 3. Waruturi movable gate, (Source: Vita Ayu Kusuma Dewi, 2014) 


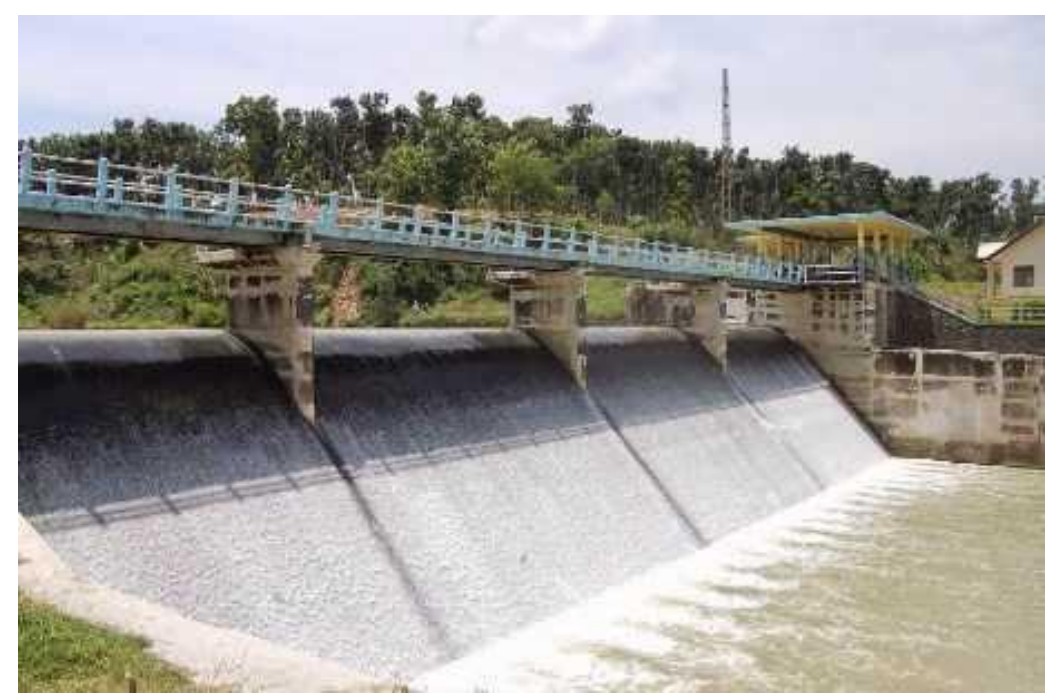

Figure 4. Fixed weir (Source: https://redalexandria.wordpress.com/2018/08/20/bendunggerak-dan-bendung-tetap/)

\section{Reservoir}

Water supply system is supported by several infrastructures. Reservoir is one of the most important facilities that must be provided to provide a water. Usually, reservoir is linked to dam as a river barrier, thus the water can be accumulated at the upstream area. The capacity of reservoir is determined by volume design as flood discharge and other needs, such as hydropower, irrigation supply, and industrial operations. Reservoir is designed for several purposes, but the most important things are to control the flood and water reserves (Su and Chen, 2019). The construction of reservoir will cause inundation that determined by topographic conditions. In general, the reservoir capacity is determined by several layers, dead storage, conservation storage, flood control, and surcharge storage. Inflow water is provided by river discharge, rainfall and spring water that exist in the reservoir basin area. Furthermore, the allocation of water for various purposes is determined as availability of water. Water level is maintained by spill structure, while the excess discharge will over flow.

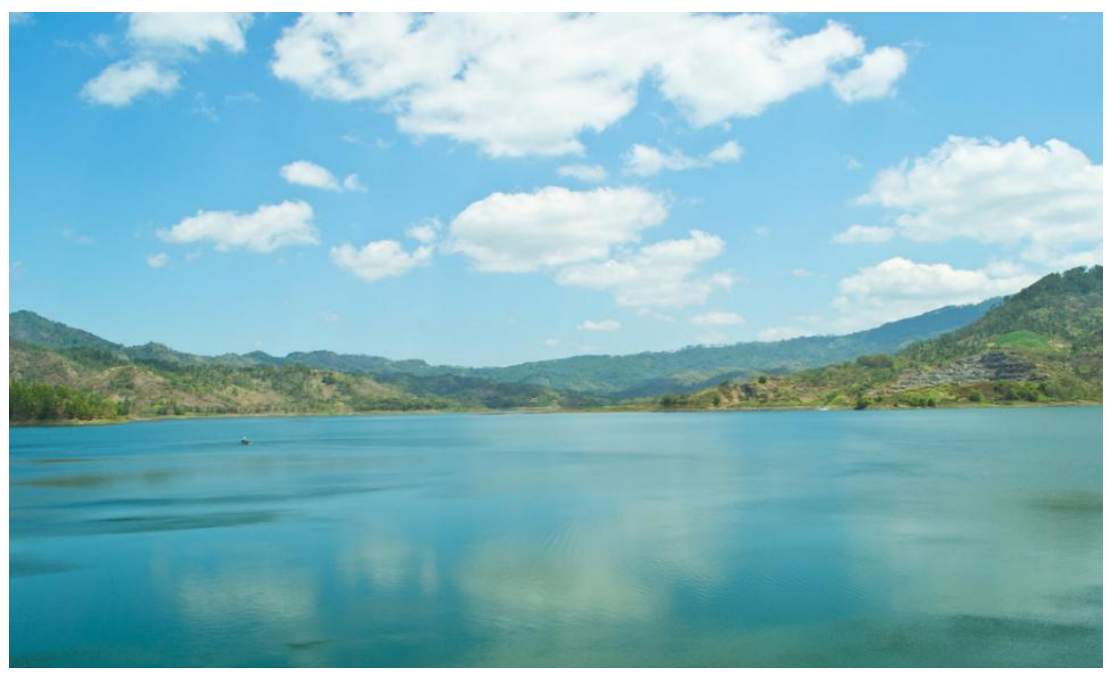

Figure 5. Wonorejo reservoir (Source:

https://www.flickr.com/photos/toms1903/7851377062/) 


\section{Irrigation Network}

Irrigation channel is designed to distribute water into cultivated land. The mechanism of water supply for irrigation system starts from dam structure which responsible to elevate the water level to the elevation target. Trough intake structure, water flow will be controlled using gate. Therefore, the irrigation channel only receives the discharge as agricultural needed. The classification of irrigation channel can be separated into three major types, primary channel, secondary channel and tertiary channel. Primary channel is the largest which flows the water from intake to the downstream channel. This channel usually constructed by stone or concrete structure for the side wall, while the bed channel is built by earth.

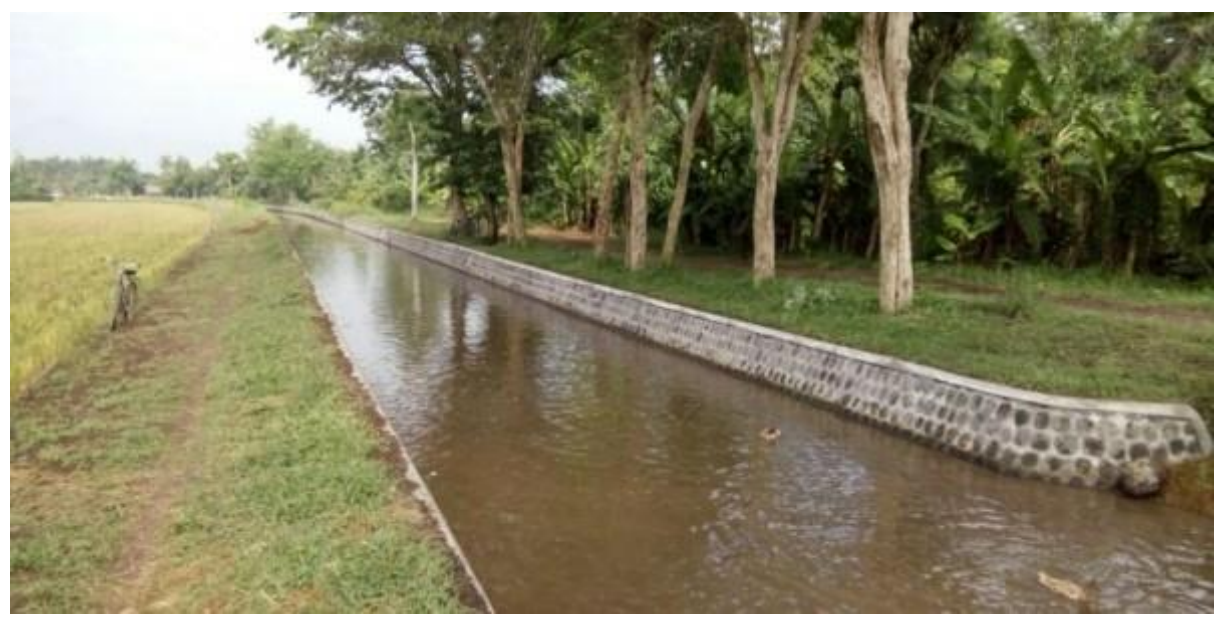

Figure 6. Irrigation channel (Source: https://www.titik0km.com/)

\section{Embankment}

Embankment is one of infrastructure that be built along the river stream in order to protect nearby area from flood and inundation. Generally, the material of embankment is earth that taken from certain quarry. The embankment height is designed based on the flood level. The most common problem encountered river embankment is sliding caused by several factors.

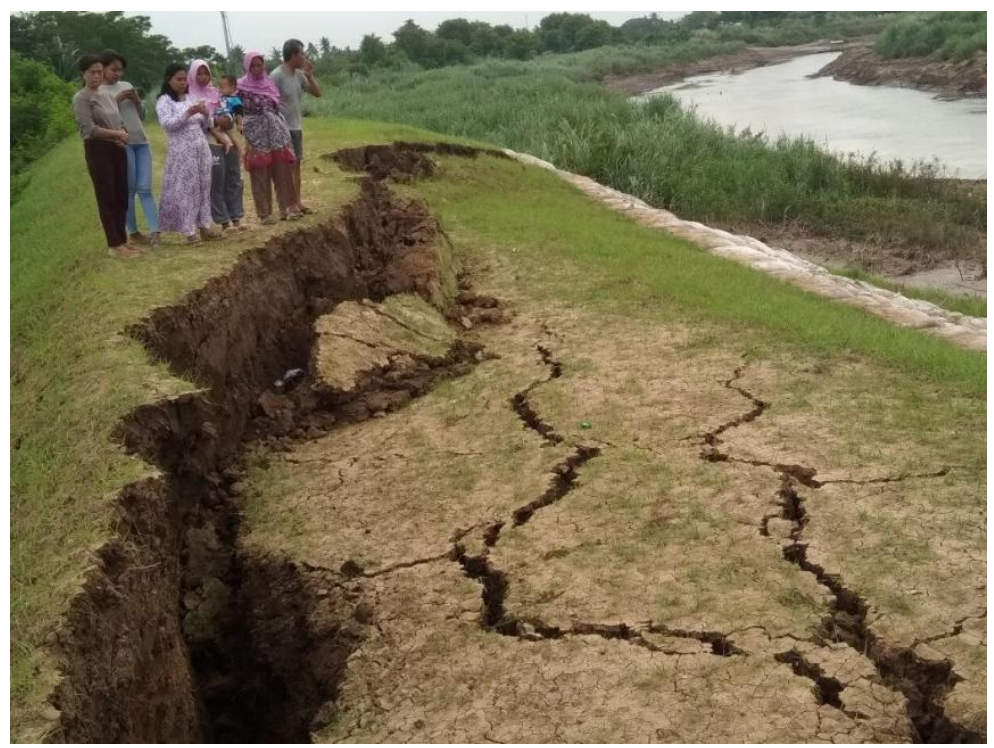

Figure 7. River embankment failure (Source: http://www.rmoljabar.com/read/2017/12/27) 
Toe embankment erosion and rapid drawdown are the main causes that often frequently. To protect the embankment structure, manmade and natural protection can be done. Gabion, geo textile, rip rap, etc. are the most popular manmade protection that can be applied in embankment, while vegetation plantation with specific type can be use in certain location.

\section{Flood Plain}

A floodplain is formed naturally based on the flood that occurs in the river. Floodplain is located on the left and right side of main channel with the outer border is a natural wall with a higher level. This area is supposed to be flooded during peak flow or high flow periods. Hence, the floodplain capacity is adjusted to the flood. Floodplain plays an important role as a flood suppression area, thus the environment along the river stream can be secured from river flow fluctuations (Jacob et al., 2017). Correspond to the sediment processes, floodplain area has dynamic condition due to sediment transport capacity and can change this area as deposition and erosion are greatly affecting (Yuniarti, 2018).

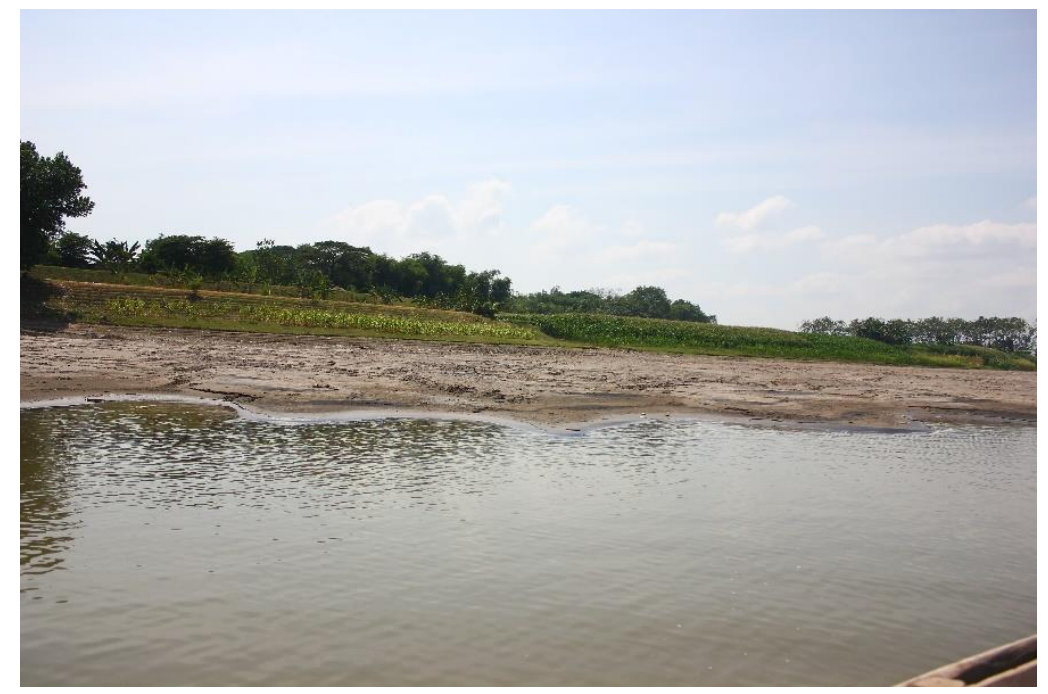

Figure 8. Floodplain of Bengawan Solo River

\section{Inspection Road}

The inspection road is required in order to maintain river infrastructures that may need some heavy equipment. Generally, the inspection road is located at one or both sides of the river that provides access to the infrastructure location. In case of infrastructure damage, some heavy equipment may require an access road to the location. This road should be able to support heavy loads, such as trucks, excavator, loaders, etc. If the access is not provided due to land limitation issue, at least there are roads that can be passed by light vehicle for routine inspections.

Due to the location of inspection roads are close to the river, the strength and stability of river bank should be noticed as the burden of heavy equipment that might pass through the road (Liu and Hounsa, 2018). In another hand, the settlement of inspection road due to heavy load should be considered otherwise the road structure would be damaged frequently (Xenaki et al., 2016). 


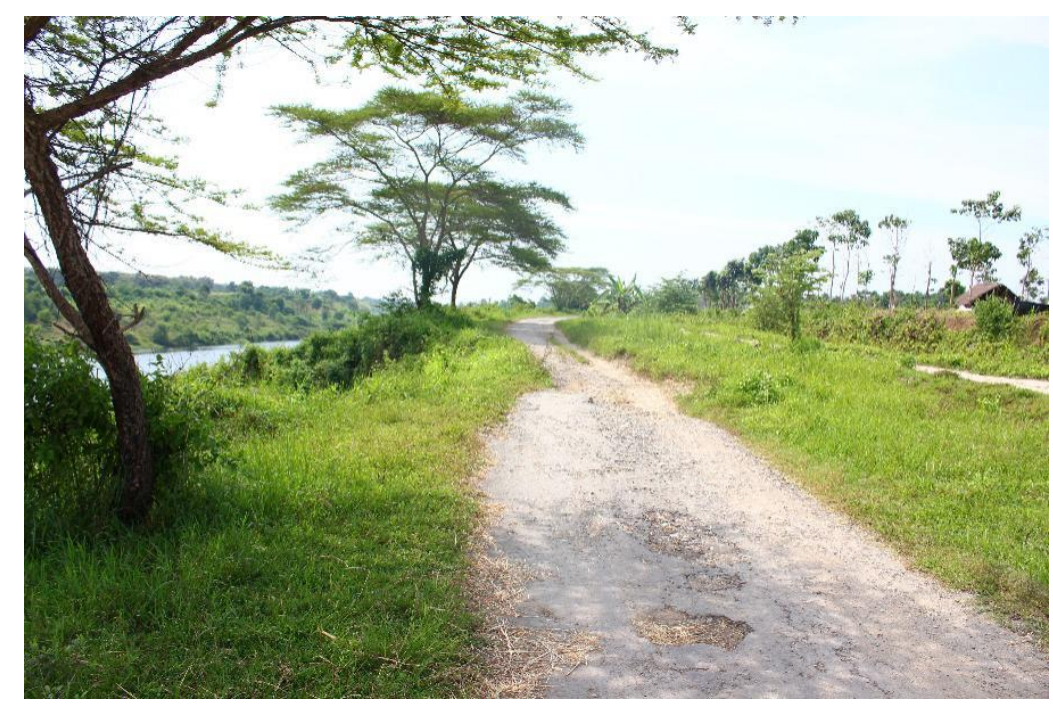

Figure 9. Inspection road of Plangwot Floodway in Lamongan, Indonesia

\section{Bridge}

River is a natural channel that flows on the path as geological and hydraulic characteristics. In many points, rivers intersect with an area that used for human activities, such as cities, industrial area, residential area, etc. In order to connect the separate area due to river stream, the bridge is constructed by considering the span of the river. In case of river floor design, it should be arranged above the flood level that probably occurs in the river (Bhatkoti et al., 2016). Many bridge failures due to miscalculation of the flood level that become horizontal load for bridge structure (Husain and Jan, 2016). The consideration of water level below the bridge can be analyzed based on return period of flood $(10,20$, or 25 years) depending on the river dimension. However, the bridge as important infrastructure should be designed properly to ensure the asset function is well maintained.

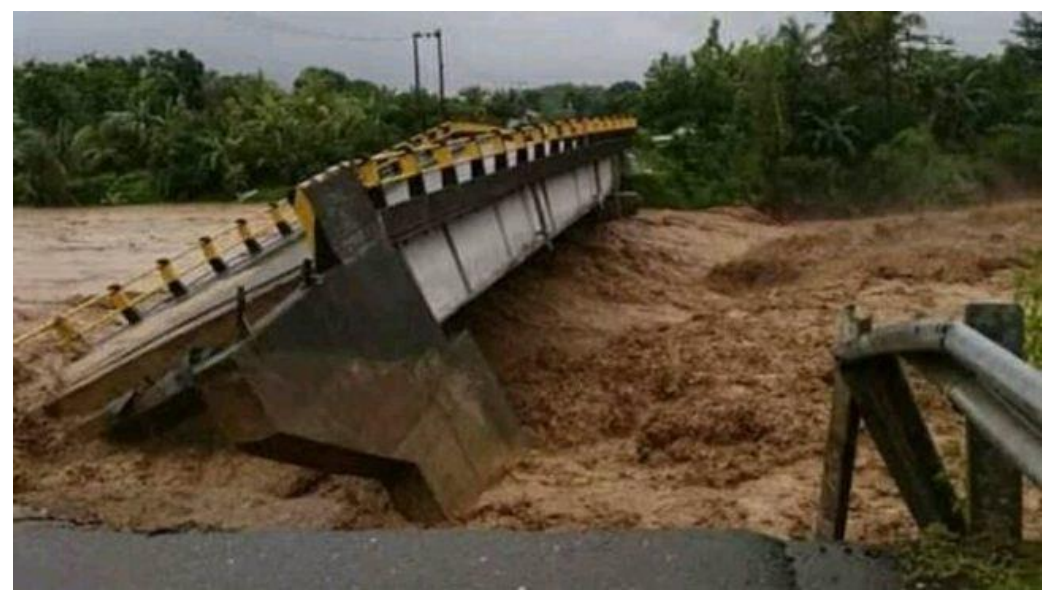

Figure 10. Bridge failure at Gowa, Sulawesi (Source: http://news.djournalist.com/read/2019/)

\section{CONCLUSION}

An effort to recognize the river infrastructure need to be done as a preliminary step in river asset management. Holistic infrastructure identification needs asset function assessment. The regulation that applied to the river system from the upstream to downstream should considering the existing infrastructure, hence an appropriate asset management could be arranged. Further work is required as many infrastructures still unlisted and unreachable due to limited access and information. 


\section{REFERENCES}

Insukindro \& Aliman (1999). "Pemilihan dan Fungsi Empirik: Studi Kasus Perminatan Uang Kartal Riil di Indonesia. Jurnal Ekonomi dan Bisnis Indonesia. Vol. 14, No. 4:49-61.

Azmat Hussain \& Sumaira Jan. (2016). "Bridge failure causes in extreme flood events". International Journal of Civil Engineering and Technology (IJCIET). Vol. 7, Issue 5, pp. 216-221, Article ID: IJCIET_07_05_023

Chengjia Su, Xiaohong Chen (2019). "Assessing the effects of reservoirs on extreme flows using nonstationary flood frequency models with the modified reservoir index as a covariate". Advances in Water Resources, Vol. 124, February 2019, Pages 29-40

Chunyuan Liu and Ulysse Seho F. Hounsa (2018). "Analysis of Road Embankment Slope Stability". Open Journal of Civil Engineering. Vol. 8 No. 2. doi: 10.4236/ojce.2018.82010

Daniel Vázquez-Tarrío, Michal Tal, Benoît Camenen, Hervé Piégay (2019). "Effects of continuous embankments and successive run-of-the-river dams on bedload transport capacities along the Rhône River, France". Science of The Total Environment, Vol. 658, 25 March 2019, Pages 1375-1389.

Elizabeth Mettetal (2019). "Irrigation dams, water and infant mortality: Evidence from South Africa”. Journal of Development Economics, Vol. 138,,pp. 17-40.

Gerald E. Galloway Jr (1995). "New directions in floodplain management". Water Resources Bulletin. 1995, https://doi.org/10.1111/j.1752-1688.1995.tb04024.x.

Gideon Johannes Bonthuys, Marco van Dijk, Giovanna Cavazzinic (2019). "Leveraging water infrastructure asset management for energy recovery and leakage reduction". Sustainable Cities and Society. Vol. 46, 101434

Ian C. Campbell (2016). "Integrated management of large rivers and their basins". Ecohydrology and Hydrobiology. Vol. 16, Issue 4, pp. $203-214$.

Jacob V. E. Katz, Carson Jeffres, J. Louise Conrad, Ted R. Sommer, Joshua Martinez, Steve Brumbaugh, Nicholas Corline, Peter B. Moyle (2017). "Floodplain farm fields provide novel rearing habitat for Chinook salmon". Journal Pone.

Jin Luo, Qi Zhang, Liang Li, Wei Xianga (2019). "Monitoring and characterizing the deformation of an earth dam in Guangxi Province, China". Engineering Geology, Vol. 248, pp. 50-60. https://doi.org/10.1371/journal.pone.0177409.

Michael Church (2006). "Bed Material Transport and the Morphology of Alluvial River Channels". Annu. Rev. Earth Planet. Sci. 34:325-54. doi: 10.1146/ annurev.earth.33.092203.122721.

O.K. Saleh, E.A. Elnikhely, Fathy Ismail (2019). "Minimizing the hydraulic side effects of weirs construction by using labyrinth weirs". Flow Measurement and Instrumentation, Vol. 66, pp. 1-11.

P.Angriani, Sumarmi, I.N.Ruja, S.Bachri (2018). "River management: The importance of the roles of the public sector and community in river preservation in Banjarmasin (A case study of the Kuin River, Banjarmasin, South Kalimantan - Indonesia)". Sustainable Cities and Society, Vol. 43, pp. 11-20.

Paulina Budryte, Sonja Heldt and Martin Denecke (2018). "Foundations of the participatory approach in the Mekong River basin management". Science of The Total Environment. Vol. 622-623, pp. 349-361.

Roma Bhatkoti, Glenn E. Moglen, F. ASCE, Pamela M. Murray-Tuite, A.M. ASCE, and Konstantinos P. Triantis (2016). "Changes to Bridge Flood Risk under Climate Change". Journal of Hydrologic Engineering. Vol. 21, issue 12.

Soemitro, R.A.A. \& Suprayitno, H. (2018). "Pemikiran Awal tentang Konsep Dasar Manajemen Aset Fasilitas". Jurnal Manajemen Aset Infrastruktur \& Fasilitas, Vol. 2, Sup. 1, Juni 2018, Hal. : 1-13. 
Suprayitno, H. \& Soemitro, R.A.A. (2018). "Preliminary Reflexion on Basic Principle of Infrastructure Asset Management". Jurnal Manajemen Aset Infrastruktur \& Fasilitas, Vol. 2, No.2, Maret 2018, Hal. : 1-9.

Xenaki, V., Doulis, G., and Athanasopoulos, G (2016). "Geotechnical Design of Embankment: Slope Stability Analyses and Settlement Calculations". International Journal of Geoengineering Case histories. 2016. Vol.3, Issue 4, p.246-261. doi: 10.4417/IJGCH-03-04-04.

Yuniarti Yuskar, Dewandra Bagus Eka Putra, Muhammad Revanda (2018). "Quarternary Sediment Characteristics of Floodplain area: Study Case at Kampar River, Rumbio Area and Surroundings, Riau Province". JGEET. 2018. Vol. 3 No. 1. doi: https://doi.org/10.24273/jgeet.2018.3.1.1226 
(e)ISSN 2656-8896 (p)ISSN 2656-890X

Journal Infrastructure Facility Asset Management - Vol. 1, Issue 1, March 2019 